\title{
- ADAPTACJA ZAWODOWA I SPOŁECZNA PIELĘGNIAREK W NOWYM MIEJSCU PRACY - WYBRANE ZAGADNIENIA
}

\section{PROFESSIONAL AND SOCIAL ADAPTATION OF NURSES AT THE NEW WORKPLACE - SELECTED ISSUES}

\author{
Bożena Ścieglińska ${ }^{1}$, Małgorzata Machaj ${ }^{2}$, Joanna Gotlib³ \\ ${ }^{1}$ Samodzielny Publiczny Dziecięcy Szpital Kliniczny w Warszawie \\ ${ }^{2}$ Dział Organizacji i Zasobów Ludzkich CSK MSW w Warszawie \\ ${ }^{3}$ Zakład Dydaktyki i Efektów Kształcenia \\ Warszawski Uniwersytet Medyczny
}

DOI: https://doi.org/10.20883/pielpol.2017.18

\begin{abstract}
STRESZCZENIE
W prezentowanej pracy przedstawiono wybrane, najważniejsze zagadnienia związane z adaptacją zawodową i społeczną pielęgniarek w nowym miejscu pracy. Przedstawiono szczegółową charakterystykę adaptacji zawodowej oraz opisano najważniejsze czynniki warunkujące przebieg adaptacji zawodowej, takie jak: rekrutacja pracownika, opis stanowiska pracy, środowisko pracy, zadania opiekuna adaptacji zawodowej, oraz rolę kwalifikacji i kompetencji pracownika w procesie adaptacji zawodowej i społecznej w nowym miejscu pracy.
\end{abstract}

SŁOWA KLUCZOWE: adaptacja zawodowa, adaptacja społeczna, pielęgniarki, zatrudnienie.

\begin{abstract}
Wstęp
Adaptacja zawodowa to proces związany z przystosowaniem pracownika do norm i zasad panujących wśrodowisku pracy, jak również akceptacja nowej funkcji i pozycji społecznej. Nowo przyjęty pracownik, włączając się w strukturę organizacji, adoptuje się do obowiązujących norm w relacji do współpracowników i przełożonych. Praktycznie przystosowuje się do nowych warunków pracy. Poznaje wymagania na objętym stanowisku pracy, z uwzględnieniem rodzaju i zakresu czynności, metod pracy, obsługi urządzeń, aparatury medycznej, fizyczno-organizacyjnych warunków, a także wymagań bezpieczeństwa i higieny pracy. Przygotowuje się do wykonywania powierzonych zadań m.in. poprzez nabycie określonych sprawności manualnych czy osiągnięcie samodzielności zawodowej.
\end{abstract}

\section{Cel pracy}

Celem niniejszej pracy jest przedstawienie najważniejszych, wybranych zagadnień związanych z adaptacją zawodową i społeczną pielęgniarek w nowym miejscu pracy.

\begin{abstract}
The present study discusses selected, most important issues associated with professional and social adaptation of nurses at the new workplace. The study presents a detailed characteristics of professional adaptation and describes key factors determining the course of professional adaptation such as: recruitment process, job description, work environment, tasks of the supervisor of professional adaptation, as well as the role of qualifications and competence of an employee in the process of professional and social adaptation at the new workplace.
\end{abstract}

KEYWORDS: professional adaptation, social adaptation, nurses, employment.

\section{Definicja adaptacji zawodowej i społecznej}

Termin „adaptacja” jest różnorodnie definiowany i używany zamiennie z terminem „przystosowanie”. Angielskie słowo induction pochodzi od wyrażenia łacińskiego, oznaczającego „wprowadzenie, pokazywanie drogi”.

Według Słownika wyrazów obcych PWN adaptacja oznacza przystosowanie się do nowego środowiska społecznego, do nowych warunków, także zmniejszenie odczuwania określonych bodźców wskutek długotrwałego działania [1].

Adaptacja społeczna to przystosowanie do norm, wzorów kulturowych, wartości i obyczajów panujących w nowej organizacji, uzyskanie równowagi między potrzebami jednostki a warunkami otoczenia społecznego, akceptacja funkcji i pozycji społecznej [2].

Nowo przyjęty pracownik włącza się w strukturę organizacji i adoptuje się do obowiązujących norm zachowań wobec współpracowników i przełożonych, zasad komunikowania się.

Adaptacja zawodowa polega na praktycznym przystosowaniu do nowych warunków pracy, z uwzględnieniem rodzaju i zakresu czynności, metod pracy, obsługi 
urządzeń, aparatury medycznej, fizyczno-organizacyjnych warunków, a także wymagań bezpieczeństwa i higieny pracy [3].

Adaptacja zawodowa przystosowuje pracownika do wykonywania powierzonych zadań poprzez nabycie sprawności manualnych, osiągnięcie samodzielności zawodowej oraz przystosowanie do fizycznego środowiska pracy.

\section{Istota adaptacji zawodowej pielęgniarek}

Przystosowanie się pracownika do środowiska pracy uwarunkowane jest adaptacją społeczną i zawodową, która dotyczy wszystkich pracowników, również grupy zawodowej pielęgniarek.

Przyjęcie nowego pracownika do pracy nie oznacza zakończenia procesu jego zatrudnienia. Adaptacja jest kolejnym etapem procesu rekrutacji, którego nadrzędne cele to: przystosowanie pracownika do warunków i wymagań na danym stanowisku pracy oraz uzyskanie w jak najkrótszym czasie oczekiwanej wydajności i umożliwienie bezstresowego rozpoczęcia pracy nowo zatrudnionej osoby. To także kształtowanie wiedzy pracownika dotyczącej przedsiębiorstwa i stanowiska, przystosowanie pracownika do panujących norm i zwyczajów, wykształcenie u pracownika właściwego podejścia do wykonywanych zadań i obowiązków oraz przyjaznej postawy wobec firmy [4].

Adresatami procesu adaptacji mogą być pracownicy: rozpoczynający pierwszą pracę, nowo przyjmowani, przekwalifikowani oraz zmieniający miejsce pracy.

Dla wielu pracowników pierwsze dni w nowej pracy to okres niepewności, niepokoju i napięcia emocjonalnego. Wtedy formuje się określona postawa wobec nowego otoczenia, która w przyszłości może decydująco wpłynąć na motywację do pracy. Dalszy rozwój zawodowy, chęć pozostania w zespole lub odejście z pracy, a nawet odejście od zawodu - to częste następstwa funkcjonowania w nowym środowisku [5].

Jeśli chcemy, aby proces adaptacji zakończył się sukcesem, a nowi pracownicy potrafili wykorzystać w pełni swoje zdolności, wiedzę i doświadczenie, to musimy zapewnić im odpowiednio zaplanowany program adaptacji.

Program powinien obejmować następujące fazy adaptacji zawodowej i społecznej:

1) wprowadzenie na stanowisko pracy,

2) praktyczne przystosowanie,

3) ocenę wyników i wnioski dotyczące dalszego rozwoju zawodowego pracownika.

W fazie wprowadzenia na stanowisko pracy pracownik zapoznaje się z historią, misją i celami organizacji, przez co kształtują się więzi i integracja pracownika z organizacją. Pracodawca zobowiązany jest zapoznać pracownika z zasadami funkcjonowania organizacji, jej regulaminem organizacyjnym oraz systemem wynagradzania, motywacji i oceny pracowniczej. Tak ogromna dawka informacji przekazana w krótkim czasie może doprowadzić do przeładowania pamięci i może się przyczynić do zwiększenia poziomu stresu u pracownika.

Praktycznym rozwiązaniem może okazać się w takiej sytuacji dostępny dokument stanowiskowy, który zawiera wymagane informacje w zakresie funkcjonowania organizacji, a z którymi pracownik w stosownym czasie może spokojnie zapoznać się.

Kolejnym etapem jest zapoznanie pracownika bezpośrednio ze stanowiskiem pracy i współpracownikami. Pracownik zapoznaje się z dokumentem opisu stanowiska pracy, z zakresem zadań i swoich obowiązków, z wyposażeniem stanowiskowym oraz uczestniczy w szkoleniach z zakresu bezpieczeństwa i higieny pracy. Od momentu rozpoczęcia pracy wymaga się szczególnie od pielęgniarki odpowiedzialności za siebie i swoje zachowanie wobec pacjenta, jego rodziny oraz współpracowników. To oni tworzą jej środowisko pracy dość mocno zróżnicowane pod względem przyjętych norm i oczekiwań, którym pielęgniarka musi sprostać.

Pacjenci i ich rodziny nie zawsze kierują się przyjętymi społecznie normami. Ich oczekiwania wobec personelu medycznego są dość zróżnicowane, a czasem nawet kontrowersyjne. Jest to duże wyzwanie dla zespołu terapeutycznego, szczególnie dla pielęgniarek, gdyż to one są najbliżej pacjenta.

Wiele pielęgniarek w pierwszych dniach pracy czuje się niepewnie. Sposób, w jaki nowa pielęgniarka zostaje wprowadzona do zespołu terapeutycznego, jest częściowym sprawdzianem podmiotowego podejścia do pracowników, którzy stanowią potencjał szpitala. $\mathrm{Na}$ etapie praktycznego przystosowania pracownika na stanowisku pracy ważną rolę odgrywa wyznaczony opiekun adaptacji zawodowej. Jest to istotne w przypadku absolwentów, którzy posiadają dużo wiedzy teoretycznej, natomiast nie mają umiejętności praktycznych. Opiekun posiadający duże doświadczenie i umiejętności zawodowe jest wielką pomocą dla nowo przyjętego pracownika w czasie nabywania doświadczenia zawodowego. Jest to szczególnie ważne dla pielęgniarek, gdyż wymaga się od nich nie tylko wiedzy zawodowej, ale również umiejętności manualnych w wykonywaniu czynności medycznych.

Nowe stanowisko pracy, urządzenia, sprzęt medyczny, obserwacja wykonywanych czynności - to bodźce mogące wywołać stres i przemęczenie pracownika. Dlatego część praktyczna adaptacji pracownika powinna być realizowana etapami z oceną ich przyswajalności. 
Zakończeniem procesu adaptacji zawodowej jest ocena pracownika. Podstawą oceny może być opinia bezpośredniego przełożonego lub arkusz ocen prowadzony przez opiekuna adaptacji. Stosowanie oceny na zakończenie procesu adaptacji stymuluje nowych pracowników i stażystów do wydajniejszej pracy, wymusza kontrolę własnych zachowań, a także umożliwia ustalenie przez przełożonych i samego pracownika przydatności do określonej pracy [6].

W przypadku pracowników z nabytym doświadczeniem $z$ innych miejsc pracy czas przewidziany na tę ocenę jest również momentem wymiany doświadczeń, które warto przeanalizować pod kątem przydatności w szpitalu.

Proces rekrutacji i selekcji jest kosztowny, czasochłonny i nie powinien zakończyć się na etapie zatrudnienia pracownika. Integralną jego częścią jest okres adaptacji zawodowej. W tym czasie następuje etap rozwinięcia motywacji do pracy i identyfikacji zawodowej pracownika, która wyraża się poprzez:

1) zaangażowanie emocjonalne na rzecz realizowanych zadań w miejscu pracy,

2) uznanie celów i zasad wspólnego działania,

3) utożsamienie interesu własnego $z$ interesem zakładu pracy,

4) utożsamienie siebie $z$ pełnioną funkcją,

5) odpowiedzialność za prawidłowe funkcjonowanie własnego zakładu pracy [5].

Tylko w takiej sytuacji rekrutacja kończy się sukcesem dla firmy oraz przynosi satysfakcję dla pracownika i wymierne korzyści dla organizacji.

\section{Czynniki warunkujące przebieg adaptacji zawodowej}

Proces adaptacji zawodowej jest wieloetapowym, przemyślanym działaniem, którego celem jest wprowadzenie nowego pracownika do pracy i zapoznanie z organizacją pracy w firmie, z kulturą organizacyjną, z procedurami, a także z wyznawanymi wartościami w organizacji [7].

Proces ten jest uwarunkowany wieloma czynnikami zależnymi zarówno od pracodawcy, jak i pracownika.

Do czynników zależnych od pracodawcy należą:

1) rekrutacja pracownika,

2) stanowisko pracy i jego opisy,

3) środowisko pracy,

4) opiekun adaptacji zawodowej,

5) motywacja do pracy.

Do czynników zależnych od pracownika należą przede wszystkim kompetencje zawodowe pracownika. Czynniki te zostały scharakteryzowane w dalszej części artykułu.

\section{Rekrutacja pracownika}

Rekrutacja to ważny proces dla pracodawcy oraz pracownika, a od jej przygotowania i przebiegu wiele zależy. To, jak zostanie przygotowana i przeprowadzona, wpłynie na sukces firmy, jak również na zadowolenie pracownika. Pozyskani pracownicy poprzez posiadane kwalifikacje i umiejętności mają wpływ na efektywność realizacji celów organizacji [8].

W odniesieniu do szpitala nabór pracowników z odpowiednimi kompetencjami przekłada się na jakość udzielanych świadczeń medycznych wobec hospitalizowanego pacjenta, co stanowi nadrzędny cel szpitala. Nieprawidłowy dobór pracowników w pionie pielęgniarskim może w istotny sposób wpłynąć na funkcjonowanie szpitala. Brak wymaganych kwalifikacji kadry pielęgniarskiej nie tylko obniża jakość udzielanych świadczeń, ale może mieć wymierny, negatywny skutek ekonomiczny, mający odzwierciedlenie przede wszystkim w obszarze roszczeń pacjentów. Negatywnymi następstwami popełnionych błędów w doborze kadry są także: nieprawidłowe wykorzystanie wyposażenia stanowiskowego, nieracjonalne zużycie sprzętu medycznego, uszkodzenie kosztownej aparatury medycznej i inne. Dlatego też, aby maksymalnie zminimalizować skutki wynikające z nieprawidłowego doboru pracowników, należy wiele uwagi poświęcić rekrutacji pracowniczej.

\section{Opis stanowiska pracy}

Stanowisko pracy jest najmniejszą, niepodzielną komórką organizacyjną przedsiębiorstwa, w której odbywa się proces pracy, wyróżniający się zarówno statycznym układem elementów, jak i dynamiką pracy ludzkiej, funkcjonowaniem maszyn i urządzeń oraz oddziaływaniem czynników otoczenia [9].

Na stanowisko pracy składa się wiele elementów, które powinny być opisane w sformalizowanym dokumencie. Opis stanowiska pracy zawiera wielopoziomową charakterystykę pracy wykonywanej na danym stanowisku oraz zbiór wymagań stawianych kandydatom na to stanowisko, co stanowi bezpośrednie odniesienie do procesu rekrutacji. Konkretna treść opisu stanowiska pracy zależy od celu, w jakim ma być ono wykorzystane. Ponieważ opis stanowiska ma służyć wielu osobom, w tym nowo przyjętym pracownikom, należy je opisywać prostym, zwięzłym językiem.

Opis powinien określać nazwę stanowiska, miejsce w strukturze organizacyjnej, cel i wymagania stanowiskowe dla pracownika, zadania i uprawnienia stanowiskowe, odpowiedzialność, zależności i współpracę z innymi jednostkami organizacyjnymi oraz kryteria oceny i warunki pracy na stanowisku. 
Z uwagi na informacje zawarte w opisie stanowiska jego zastosowanie zachodzi w trzech podstawowych obszarach: zarządzania organizacją pracy, zarządzania zasobami ludzkimi oraz kierowania ludźmi.

W obszarze organizacji pracy opisy stanowisk prowadzą do standaryzacji określonych procedur postępowania, co pozwala na tworzenie i modyfikacje struktury organizacyjnej. Pozwalają również wykrywać nieprawidłowości w istniejącej organizacji pracy i w konsekwencji - usuwać je. Przekłada się to na eliminację zbędnych czynności wykonywanych w pracy, łączenie stanowisk lub przenoszenie niektórych zadań na inne stanowiska. Opisy stanowisk pracy stanowią istotę w ocenie warunków pracy, co przekłada się na zapewnienie bezpieczeństwa i higieny, a także warunków ergonomicznych pracy.

W obszarze zarządzania zasobami ludzkimi opisy stanowisk pracy odgrywają istotną rolę w rekrutacji odpowiedniego pracownika. Dzieje się tak dzięki profilom kompetencyjnym stanowiska, określającym wymagane i pożądane kompetencje wraz z kwalifikacjami pracownika, co w przyszłości przekłada się na efektywne wykonywanie zadań związanych z tym stanowiskiem.

Dokonywanie awansów, przesunięć i degradacji jest łatwiejsze, gdy istnieje możliwość posługiwania się opisami pracy i profilami wymagań kandydatów.

Ocena trudności pracy dokonana na podstawie opisów pracy pozwala na przeprowadzenie procesu wartościowania pracy i ustalania stawek płacowych. Porównanie profili kwalifikacyjnych na dane stanowiska z kwalifikacjami zajmujących je pracowników bardzo przydaje się podczas identyfikacji potrzeb szkoleniowych oraz planowania ścieżki rozwoju pracownika [10].

W okresie adaptacji nowo przyjętego pracownika opis stanowiska pracy wywiera istotny wpływ na skuteczność przebiegu tego procesu. Opis stanowiskowy pozwala nowemu pracownikowi zapoznać się z istotą stanowiska, na którym pracuje. Stanowi charakterystykę rodzaju pracy i warunków pracy, określa wymagane kompetencje, aby sprawnie wypełniać powierzoną rolę organizacyjną [10].

W obszarze kierowania ludźmi opisy stanowisk pracy stanowią narzędzie w realizacji zadań kierowniczych. Na podstawie informacji zawartych w opisach stanowisk można lepiej zaplanować pracę zespołu, ustalić wzajemne relacje między pracownikami.

Łatwiej można organizować i kontrolować prace pracownika na danym stanowisku. W efekcie usprawnia to proces decyzyjny ułatwia ocenianie pracowników i zmniejsza ryzyko powstawania konfliktów [10].

Przez wzgląd na ważność dokumentu, jakim jest opis stanowiska pracy, zarówno w procesie zarządzania, jak i przebiegu adaptacji zawodowej pracownika, w dalszej części pracy uszczegółowiono opis wymie- nionych powyżej elementów stanowiskowych w odniesieniu do stanowisk pielęgniarskich i regulacji prawnych dotyczących wykonywania zawodu pielęgniarki.

Nazwa stanowiska pracy powinna odnosić się do zadań i czynności przypisanych do stanowiska pracy oraz nawiązywać do struktury organizacyjnej, w której stanowisko funkcjonuje.

W odniesieniu do stanowisk pielęgniarskich ich nazewnictwo ujęte jest w Rozporządzeniu Ministra Zdrowia z dnia 20 lipca 2011 r. w sprawie kwalifikacji wymaganych od pracowników na poszczególnych rodzajach stanowisk pracy $w$ podmiotach leczniczych niebędących przedsiębiorcami (Dz.U. Nr 151, poz. 869).
A. Stanowiska kierownicze:
1) naczelna pielęgniarka,
2) pielęgniarka oddziałowa,
3) zastępca pielęgniarki oddziałowej,
4) pielęgniarka koordynująca.
B. Stanowiska wykonawcze:
1) pielęgniarka anestezjologiczna,
2) pielęgniarka operacyjna,
3) specjalista w dziedzinie pielęgniarstwa,
4) starsza pielęgniarka,
5) pielęgniarka.

Ich nazwy są spójne z zadaniami przypisanymi do stanowisk i obszarem działań. W obszarze podległości stanowiska te wskazują na gradację stanowisk w strukturze pionu pielęgniarskiego.

\section{Miejsce stanowiska pracy w strukturze organizacji}

Każde stanowisko pracy powinno być zidentyfikowane w strukturze organizacji poprzez informacje zawierające nazwę jednostki organizacyjnej, nazwę pionu i komórki organizacyjnej, w której funkcjonuje stanowisko. Dla zachowania ciągłości wykonywania zadań na stanowisku istotnym elementem jest określenie powiązań funkcjonalnych z innymi stanowiskami czy też komórkami organizacyjnymi, np. w obszarze zastępstw.

W odniesieniu do hierarchii podległości stanowisk pielęgniarskich należy wymienić podległość bezpośrednią, pośrednią, funkcjonalną i merytoryczną.

Stanowiska pielęgniarskie przypisane są do pionu medycznego i funkcjonują w poszczególnych komórkach organizacyjnych realizujących świadczenia medyczne. Pielęgniarki z zadaniami kierowniczymi bezpośrednio podlegają naczelnej pielęgniarce, funkcjonalnie - kierownikowi komórki organizacyjnej. Pielęgniarki z zadaniami wykonawczymi podlegają pośrednio naczelnej pielęgniarce, bezpośrednio - pielęgniarce oddziałowej, funkcjonalnie - kierownikowi komórki organizacyjnej. 
W odniesieniu do statusu wykonywania zawodu pielęgniarka merytorycznie podlega wyłącznie pielęgniarce.

\section{Cel stanowiska}

Cel istnienia stanowiska pracy powinien wskazywać, co stanowi o głównej wartości opisywanego stanowiska pracy dla organizacji, oraz jak pracownik przyczynia się do realizacji misji i strategii instytucji [11].

W praktyce może być to kilka celów szczegółowych, które przyczyniają się do osiągnięcia głównego celu organizacji.

Do zadań szpitala należy udzielanie świadczeń medycznych w warunkach stacjonarnych oraz ambulatoryjnych w obszarze wysokospecjalistycznych działań medycznych, realizowanych w poszczególnych oddziałach klinicznych szpitala. Pracownicy zatrudnieni na poszczególnych stanowiskach poprzez realizację szczegółowych celów stanowiskowych realizują powyższe główne cele i zadania szpitala.

Dla stanowisk kierowniczych pionu pielęgniarskiego szpitala cele główne to organizowanie i realizacja kompleksowych świadczeń pielęgniarskich, natomiast dla stanowisk wykonawczych celem głównym jest udzielanie świadczeń medycznych i pielęgniarskich hospitalizowanym pacjentom, według obowiązujących standardów. Dążeniem wszystkich pracowników szpitala powinno być osiągnięcie wyznaczonych celów na optymalnym poziomie ilościowym i jakościowym.

\section{Wymagania stanowiskowe}

Określają one niezbędne i pożądane wykształcenie, staż pracy, umiejętności oraz oczekiwane cechy osobowości pracownika.

Zawód pielęgniarki może wykonywać osoba posiadająca tytuł zawodowy, uzyskany w drodze kształcenia przeddyplomowego, oraz prawo wykonywania zawodu stwierdzone przez właściwą Okręgową Radę Pielęgniarek i Położnych.

Wymogi kwalifikacyjne do samodzielnego wykonywania świadczeń medycznych określa Rozporządzenie Ministra Zdrowia z dnia 7 listopada 2007 r. w sprawie rodzaju i zakresu świadczeń zapobiegawczych, diagnostycznych, leczniczych $i$ rehabilitacyjnych udzielanych przez pielęgniarkę albo położną samodzielnie bez zlecenia lekarskiego (Dz.U. Nr 210, poz. 1540).

Do wykonywania określonych świadczeń pielęgniarskich pielęgniarka musi posiadać wiedzę i umiejętności uzyskane w trakcie kształcenia podyplomowego. Niektóre z tych czynności mogą być wykonywane tylko i wyłącznie pod warunkiem uzyskania tytułu specjalisty lub ukończenia kursu kwalifikacyjnego lub specjalistycznego.
Wymogi co do wykształcenia, kwalifikacji oraz stażu pracy na stanowiskach pracy pielęgniarek określa Rozporządzenie Ministra Zdrowia z dnia 20 lipca 2011 r. w sprawie kwalifikacji wymaganych od pracowników na poszczególnych rodzajach stanowisk pracy w podmiotach leczniczych niebędących przedsiębiorcami (Dz.U. Nr 151, poz. 869).

Biorąc pod uwagę fakt, że dla uzyskania pełnej efektywności pracy niezbędne są zazwyczaj pozyskanie doświadczenia i wykształcenie odpowiednich kompetencji, istotnych dla organizacji, korzystne jest rozdzielenie wymagań koniecznych do rozpoczęcia pracy na danym stanowisku oraz kompetencji niezbędnych do realizowania w pełni zadań stanowiskowych [12].

Wymagania stanowiskowe stanowią nie tylko niezbędny element w ogłoszeniu rekrutacyjnym, ale są również głównymi kryteriami w ocenie pracownika i planowaniu jego rozwoju zawodowego.

Różnice w oczekiwaniach w zakresie cech pracowników pomiędzy różnymi stanowiskami wskazują na potencjalne drogi rozwoju w organizacji, ułatwiają planowanie kariery i definiują kryteria sukcesu w zakresie realizacji indywidualnych planów i rozwoju zawodowego [12].

\section{Zadania stanowiskowe}

Zadania określone dla stanowiska pracy muszą być adekwatne do wyznaczonych celów stanowiskowych, gdyż stanowią istotę ich realizacji.

Poziom szczegółowości opisu poszczególnych zadań powinien być dostosowany do hierarchii organizacji stanowiska.

Zadania realizowane na wyższych stanowiskach powinny być określone mniej szczegółowo niż zadania realizowane na stanowiskach wykonawczych [12].

W odniesieniu do stanowisk pielęgniarskich ustalenie zadań stanowiskowych wymaga uwzględnienia wiedzy i umiejętności, których pielęgniarki nabywają w trakcie kształcenia przeddyplomowego i podyplomowego, oraz ich spójności z obowiązującymi regulacjami prawnymi dotyczącymi wykonywania zawodu pielęgniarki.

Zasady wykonywania zawodu przez pielęgniarkę i położną zostały uregulowane w Ustawie z dnia 15 lipca 2011 r. o zawodach pielęgniarki i położnej (Dz.U. Nr 174, poz. 1039), zaś wymóg posiadanych kwalifikacji do ich realizacji określa cytowane wcześniej Rozporządzenie Ministra Zdrowia z dnia 7 listopada 2007 r. w sprawie rodzaju i zakresu świadczeń zapobiegawczych, diagnostycznych, leczniczych i rehabilitacyjnych udzielanych przez pielęgniarkę albo położną samodzielnie bez zlecenia lekarskiego.

W myśl obowiązujących przepisów wykonywanie zawodu pielęgniarki polega na udzielaniu świadczeń zdrowotnych, a w szczególności świadczeń pielęgna- 
cyjnych, zapobiegawczych, leczniczych, rehabilitacyjnych oraz z zakresu promocji zdrowia przez osobę posiadającą wymagane kwalifikacje, potwierdzone odpowiednimi dokumentami.

Świadczenia te pielęgniarka wykonuje przede wszystkim poprzez: rozpoznawanie warunków i potrzeb zdrowotnych; rozpoznawanie problemów pielęgnacyjnych; sprawowanie opieki pielęgnacyjnej; realizację zleceń lekarskich w procesie diagnostyki, leczenia i rehabilitacji i ich samodzielne udzielanie w określonym zakresie.

Za wykonywanie zawodu pielęgniarki przez osobę posiadającą wymagane kwalifikacje uważa się również nauczanie zawodu pielęgniarki, prowadzenie prac naukowo-badawczych w dziedzinach pielęgniarstwa oraz kierowanie zespołem pielęgniarek i położnych.

Zatem niedopuszczalne jest wykonywanie przez pielęgniarkę lub położną czynności nienależących do jej ustawowych kompetencji.

Należy z całą stanowczością podkreślić, że w przypadku kiedy pracodawca zleca pielęgniarce/położnej wykonywanie czynności, do których nie ma ona kwalifikacji i uprawnień, może ona odmówić ich wykonania. Taka uzasadniona odmowa nie upoważnia pracodawcy do rozwiązania z pracownikiem umowy o prace - ani w trybie dyscyplinarnym, ani w drodze rozwiązania za wypowiedzeniem [13].

W odniesieniu do powyższego twierdzenia należy jeszcze raz podkreślić znaczenie zadań stanowiskowych zarówno dla pracodawcy, jak i dla samego pracownika.

W kontekście wykonywania zawodu pielęgniarki przypisanie zadań będących poza sferą jej uprawnień zawodowych i ich wykonanie będzie dla niej skutkowało odpowiedzialnością zawodową, cywilną bądź karną.

\section{Uprawnienia stanowiskowe}

Uprawnienie w ogólnym rozumieniu to wyznaczona przez prawo możliwość postępowania w określony sposób [7].

Uprawnienia stanowiskowe można podzielić na uprawnienia:

1) pracownicze, wynikające z przepisów Kodeksu pracy, regulaminów organizacyjnych,

2) stanowiskowe, wynikające $z$ przypisanych zadań na stanowisku pracy,

3) zawodowe, wynikające $z$ regulacji prawnych wykonywania zawodu.

W punkcie opisu stanowiska, odnoszącym się do uprawnień stanowiskowych, należy wpisać wszystkie formalne uprawnienia, jakie są związane z pracą wykonywaną na danym stanowisku pracy. W opisie stanowiska pracy nie wpisuje się uprawnień pracowniczych wynikających z przepisów Kodeksu pracy, a także za- wartych w regulaminach organizacyjnych czy też regulaminach wynagradzania. Nie wpisuje się również uprawnień, które są przyznawane danemu pracownikowi ze względu na jego szczególne kompetencje lub umiejętności, a które nie są związane z zakresem opisywanego stanowiska pracy. Takie zapisy umieszcza się w dokumencie, jakim jest szczegółowy zakres obowiązków pracownika.

W odniesieniu do stanowisk kierowniczych uprawnienia stanowiskowe, takie jak: kontrola, ocena, wnioskowanie, opracowywanie, planowanie, odnoszą się ściśle do zadań stanowiskowych. Dla stanowisk kierowniczych pielęgniarskich są to organizowanie i realizacja kompleksowych świadczeń pielęgniarskich w szpitalu na optymalnym poziomie poprzez nadzorowanie i organizowanie pracy podległego personelu.

W odniesieniu do stanowisk wykonawczych pielęgniarek mają zastosowanie uprawnienia zawodowe, określone przez Ministra Zdrowia w zakresie:

1) rodzaju i zakresu świadczeń zapobiegawczych, diagnostycznych, leczniczych i rehabilitacyjnych, które mogą być udzielone przez pielęgniarkę na zlecenie lekarza lub samodzielnie bez zlecenia lekarskiego;

2) stosowania przez pielęgniarkę, bez zlecenia lekarskiego, środków pomocniczych oraz produktów leczniczych;

3) rodzaju materiałów biologicznych, które mogą być pobierane przez pielęgniarkę do celów diagnostycznych samodzielnie, bez zlecenia lekarskiego;

4) rodzaju i zakresu medycznych czynności ratunkowych wykonywanych przez pielęgniarkę;

5) badań diagnostycznych przeprowadzonych samodzielnie przez pielęgniarkę.

Pielęgniarka ma również prawo odmowy wykonania pisemnego zlecenia lekarskiego, jednakże taka sytuacja może zajść tylko w wyjątkowych okolicznościach, którymi są:

1) wstrzymanie się pielęgniarki od wykonania zlecenia lekarskiego podyktowane pojawieniem się, po podjęciu decyzji przez lekarza, nowych okoliczności wymagających weryfikacji postępowania leczniczego lub wręcz stojących w sprzeczności z nim. Pielęgniarka może zaobserwować u pacjenta objawy wskazujące na konieczność wstrzymania i/lub wycofania się z kontynuacji zaordynowanego działania medycznego;

2) wykonanie świadczenia zdrowotnego niezgodne z jej sumieniem, pod warunkiem, że odmowa wykonania świadczenia medycznego nie stanowi zagrożenia dla zdrowia lub życia pacjenta; 
3) zakres wykonania świadczenia medycznego niezgodny z posiadanymi przez nią kwalifikacjami [14].

Pielęgniarka musi podać niezwłocznie przyczynę odmowy na piśmie swojemu przełożonemu lub osobie zlecającej, czyli lekarzowi (art. 12 ust. 2 Ustawy z dnia 15 lipca 2011 r. o zawodach pielęgniarki i położnej (Dz.U. Nr 174, poz. 1039) - dalej: u.z.p.p.).

Ponadto pielęgniarka ma obowiązek niezwłocznego uprzedzenia pacjenta, jego przedstawiciela ustawowego bądź opiekuna faktycznego o takiej odmowie i wskazania realnych możliwości uzyskania tego świadczenia u innej pielęgniarki, położnej lub w innym podmiocie leczniczym (art. 12 ust. 3 u.z.p.p.).

Niezależnie od podania w formie pisemnej przyczyny odstąpienia od wykonania zlecenia pielęgniarka ma obowiązek uzasadnić i odnotować ten fakt w dokumentacji medycznej pacjenta (art. 12 ust. 4 u.z.p.p.) [14].

\section{Odpowiedzialność stanowiskowa}

Odpowiedzialność to obowiązek ponoszenia przewidzianych przez przepisy prawne konsekwencji zachowania się własnego lub innych osób. W zależności od przyjętego dla jej ustalenia kryterium rozróżnia się wiele rodzajów odpowiedzialności: cywilną, karną, konstytucyjną, polityczną, prawną.

Odpowiedzialność prawna oznacza konieczność ponoszenia konsekwencji przewidzianych przez przepisy prawne.

Odpowiedzialność służbowa/stanowiskowa stanowi zobowiązanie pracownika do wykonywania zadań określonych przez pracodawcę i ponoszenie odpowiedzialności za działania w tym zakresie. Zadania te są określone w zakresie obowiązków pracownika na danym stanowisku pracy i w ramach określonej funkcji. Za niewywiązanie się z powierzonych obowiązków i przyjętych przez pracownika zadań pracodawca może stosować kary dyscyplinarne, zgodne z Kodeksem pracy lub regulaminem organizacyjnym zakładu pracy.

Odpowiedzialność karna związana jest z naruszeniem przez pracownika zasad zapisanych w prawie obowiązującym społeczeństwo. Konsekwencje i postępowanie w razie naruszenia określa Kodeks karny.

Odpowiedzialność cywilna jest to obowiązek wynagrodzenia wyrządzonej szkody lub straty przez pracownika. Ma ona charakter majątkowy. W zakresie odpowiedzialności cywilnej orzekają sądy powszechne.

Odpowiedzialność materialna określona przez Kodeks pracy to konieczność ponoszenia przez pracownika konsekwencji za szkodę wyrządzoną zakładowi pracy. Pracownik ponosi odpowiedzialność materialną za sprzęt, jaki został mu powierzony do realizacji zadań zawodowych wynikających z zakresu obowiązków czy regulaminu pracy.

\section{Odpowiedzialność zawodowa}

To obowiązek moralny lub prawny ponoszenia konsekwencji za wykonane osobiście lub polecone innej osobie do wykonania czynności zawodowe lub za ich zaniedbanie bądź zaniechanie. Jest związana z przynależnością do określonej grupy zawodowej i wiąże się z interpretacją przyjętych przez tę grupę norm [15].

Pielęgniarka ponosi odpowiedzialność zarówno pracowniczą, jak i zawodową, którą określają:

1) przepisy regulujące wykonywanie zawodu pielęgniarki i zawodu położnej,

2) Kodeks pracy,

3) Kodeks karny,

4) Kodeks cywilny,

5) regulaminy zakładowe,

6) zakresy obowiązków, uprawnień, odpowiedzialności na stanowisku pracy,

7) Kodeks etyki zawodowej polskiej pielęgniarki i położnej.

Tworząc obszary odpowiedzialności, pamiętać należy, że są one tylko narzędziem do zarządzania pracownikami. Pracodawca powinien nie tylko egzekwować od pracownika wykonanie przydzielonych mu w tym dokumencie obowiązków, ale także i sam nie przekraczać granic z nich wynikających [16].

\section{Opis stanowiska pracy a zakres obowiązków}

Opis stanowiska pracy jest elementem struktury organizacji. Dokumentem odnoszącym się w swoich zapisach bezpośrednio do pracownika jest zakres czynności, który uszczegóławia opis stanowiska dla konkretnego pracownika.

Obowiązek nałożony na pracodawcę dotyczący zapoznania pracownika z jego obowiązkami wynika z przepisów Ustawy z dnia 26 czerwca 1974 r. - Kodeks pracy (tekst jedn.: Dz.U. z 1998 r. Nr 21, poz. 94 z późn. zm.) - dalej: k.p.

W art. 94 pkt 1 przywołanej ustawy ustawodawca nakazał pracodawcy zaznajomić pracownika podejmującego pracę z zakresem jego obowiązków i sposobem wykonywania pracy na wyznaczonym stanowisku, oraz z jego podstawowymi uprawnieniami. Powinno się to odbywać przy zawieraniu umowy przed podjęciem pracy. Nie ma przy tym jednoznacznego określenia, w jakiej formie ma to nastąpić.

Podstawowym zadaniem dokumentu określającego zakres obowiązków jest sprecyzowanie oczekiwań pracodawcy wobec pracownika oraz świadczeń pracowniczych, które pracownik jest zobowiązany realizować na rzecz pracodawcy. Dokument ten jest ważny dla kształ- 
towania prawidłowych relacji pomiędzy pracownikiem a pracodawcą, gdyż stanowi jedno z podstawowych kryteriów rozliczania pracownika przez pracodawce oraz rozstrzygania sporów kompetencyjnych [16].

Wraz z wskazanymi zadaniami przypisuje się pracownikowi odpowiedzialność za wykonane zadania, co przekłada się na przeniesienie na pracownika części odpowiedzialności za prawidłowe funkcjonowanie organizacji. Tylko w takim ujęciu możemy oczekiwać, że pracownik będzie czuł się współgospodarzem zakładu pracy i zidentyfikuje się z nim [16].

Samo wypunktowanie zadań pracowniczych jest niewystarczające. Pracownik powinien mieć również sprecyzowane zasady odpowiedzialności oraz powinien mieć zapewnione warunki, aby mógł ją ponosić. Brak określenia obszaru samodzielności pracownika skutkuje niemożnością egzekwowania jego odpowiedzialności, co przekłada się na skutki prawne takiej sytuacji.

Wyrok Sądu Najwyższego z dnia 7 stycznia 1998 r. (I PKN 457/97, OSNAPiUS 1998, Nr 22, poz. 653) wskazuje, że pracownik nie powinien ponosić negatywnych skutków niedoinformowania. Przyjęte jest bowiem, że zatrudniony nie ponosi odpowiedzialności za niewykonanie obowiązku, o którym nie został poinformowany. Jeżeli więc pracodawca nie zapozna podwładnego z zakresem jego zadań, musi liczyć się, że zarzut niedopełnienia obowiązków pracowniczych może być niezasadny, a w przypadku wyrządzenia szkody stanowić może uzasadnienie dla uznania, iż do jej powstania albo zwiększenia przyczynił się pracodawca we własnej osobie (por. art. 117 k.p.) [17].

Brak pisemnego zakresu obowiązków nie stanowi przesłanki, która zwalnia pracownika od wykonywania obowiązków służbowych, zwłaszcza tych oczywistych.

W przypadku jakichkolwiek wątpliwości zainteresowany, w ramach ciążącego na nim obowiązku dbałości o dobro zakładu pracy (por. art. 100 § 2 k.p.), powinien podjąć wszelkie możliwe starania prowadzące do zapoznania się z obowiązkami zawodowymi. W przeciwnym razie ponosi on skutki wadliwego ich wykonania (por. wyrok SN z dnia 7 stycznia 1998 r., I PKN 457/97, OSNAPiUS 1998, Nr 22, poz. 653). Jednocześnie SN stwierdza w wyroku, iż odmowa przyjęcia i podpisania zakresu czynności ustalonego zgodnie z umową o pracę może stanowić uzasadnioną przyczynę jej wypowiedzenia (por. wyrok SN z dnia 3 kwietnia 1997 r., I PKN 77/97, OSNP 1998/3/75).

Korzyści wynikające z posiadania dokumentów, jakimi są opisy stanowiska pracy i szczegółowe zakresy zadań i obowiązków, są wymierne zarówno dla pracodawcy, jak i pracownika.

Korzyści dla pracodawcy przekładają się na zarządzanie zasobami ludzkimi, w tym realizację polityki zatrudnienia, wartościowanie stanowisk pracy, ocenę pracownika, system wynagradzania i związany z nim system motywowania. W odniesieniu do rozpatrywania roszczeń pracowniczych na drodze prawnej stanowią dokument, do którego w swoich wyjaśnieniach może odwoływać się pracodawca.

Korzyści dla pracownika przekładają się na jego samorealizację. Dzięki opisowi stanowiska pracownik może dokładnie zapoznać się ze swoim miejscem i rolą w organizacji. Znając miejsce stanowiska w hierarchii, może także zaplanować własną karierę w organizacji. Istnienie możliwości takiej kariery wpływa pozytywnie na lojalność pracownika wobec pracodawcy. Pracownik może także zaplanować ścieżkę swego dalszego rozwoju zawodowego. Tym bardziej że opis stanowiska pracy pomaga mu zrozumieć kryteria oceny. Te dwa elementy sprzyjają z kolei samomotywowaniu. Zakres wykonywanych obowiązków i ich rekomendacja przez poprzedniego pracodawcę mogą stanowić istotny i korzystny dla kandydata element rekrutacyjny w przyszłej pracy.

Korzyści dla menedżerów przekładają się na efektywne zarządzanie podległym personelem. Dysponując opisami stanowisk pracy, menedżerowie mają ułatwione organizowanie pracy i motywowanie podległych pracowników. Posiadają także jasne kryteria zatrudnienia i oceny pracowników. Mogą wspierać pracowników przy tworzeniu ścieżek karier i określeniu potrzeb szkoleniowych.

Podsumowując, warto podkreślić znaczenie opisu stanowiska pracy i szczegółowego zakresu obowiązków - zarówno dla pracownika, jak i pracodawcy. Dokumenty te stanowią o jakości funkcjonowania określonego stanowiska pracy w organizacji, która jest nastawiona na realizację ściśle określonych celów, którymi w przypadku szpitala są przede wszystkim poprawa zdrowia i satysfakcja pacjentów.

\section{Środowisko pracy}

Środowisko pracy tworzy zespół czynników materialnych i społecznych, z którymi styka się pracownik podczas wykonywania pracy, począwszy od urządzeń mechanicznych, poprzez natężenie hałasu, oświetlenia, skończywszy na temperaturze otoczenia. Istotne jest wyselekcjonowanie czynników mogących powodować zagrożenie dla zdrowia, a nawet życia pracownika.

Praca pielęgniarki jest wysoce zróżnicowana pod względem obowiązków i wykonywanych czynności. Innemu obciążeniu podlega pielęgniarka zatrudniona tylko na zmianie porannej, innemu - w trybie pracy zmianowej. Obowiązki pielęgniarki instrumentariuszki różnią się od obowiązków pielęgniarki odcinkowej oddziału terapii zachowawczej. Do obowiązków pielęgniarek mogą należeć czynności związane z transferem 
i wewnętrznym transportem chorych, wówczas pracy tej towarzyszy duży wysiłek fizyczny [18].

W środowisku pracy personelu medycznego występuje wiele problemów biomechanicznych, wpływających na układ ruchu, co przy nieprawidłowej organizacji pracy narusza jej bezpieczeństwo i higienę. Uciążliwości związane z wykonywaniem konkretnych czynności, skutkujących wysiłkiem statycznym, długotrwałym zajmowaniem jednej pozycji, charakterystycznej dla pracy zespołów operacyjnych, skutkują zmęczeniem układu ruchu.

W obszarze bloków operacyjnych jest to pole elektromagnetyczne i jonizujące, a przy leczeniu chemioterapią - czynnik toksyczny, jakim jest cytostatyk.

Poważnym zagrożeniem są również stosowane podczas udzielania świadczeń medycznych ostre narzędzia (igły, kanikule dożylne, ostrza, nakłuwacze), których nieumiejętne używanie skutkuje zranieniem i ekspozycją zawodową. Jest to istotny problem w przypadku adaptacji pracownika, który nie posiada wypracowanych umiejętności posługiwania się tego rodzaju sprzętem medycznym. Dzięki stosowaniu bezpiecznego sprzętu medycznego (np. bezpieczne kaniule dożylne) i prawidłowej organizacji pracy na stanowiskach zabiegowych oraz prowadzenia ustawicznego doskonalenia zawodowego skutki wynikające z wystąpienia ekspozycji zawodowej są minimalizowane.

W celu zminimalizowania skutków działania czynników szkodliwych występujących w środowisku pracy pielęgniarek należy wypracować metody pracy z wykorzystaniem bezpiecznego sprzętu medycznego, a poprzez prawidłową organizację pracy należy minimalizować skutki uboczne wynikające ze zmianowego systemu pracy pielęgniarek, obejmującego porę nocną.

Podstawowym i najważniejszym w omawianym zakresie aktem prawnym jest Ustawa z dnia 30 marca $1965 \mathrm{r}$. o bezpieczeństwie i higienie pracy (Dz.U. z 1965 Nr 13, poz. 91). Przywołana ustawa zawiera przepisy określające obowiązki pracodawcy i innych osób odpowiedzialnych za bezpieczeństwo i higienę pracy. M.in. określony został obowiązek pracodawcy do opracowania kart oceny ryzyka zawodowego dla stanowisk pracy. Karta oceny ryzyka zawodowego umożliwia pracodawcy i pracownikowi dokonanie analizy stanowiska pracy pod względem jego bezpieczeństwa, co wydaje się zasadne wobec możliwych negatywnych następstw.

\section{Opiekun adaptacji zawodowej}

Wdrażanie pracownika na stanowisko pracy powinno być procesem zaplanowanym. Specjaliści z zakresu zarządzania zasobami ludzkimi wskazują na istotną rolę w tym procesie wyznaczonej osoby, pełniącej funkcję opiekuna procesu adaptacji. Funkcję tę może pełnić bezpośredni przełożony lub wyznaczony pracownik.
Z uwagi na znaczenie roli opiekuna w przebiegu procesu adaptacji zawodowej niezbędnym wydaje się określenie i rozpoznanie predyspozycji osób pełniących taką funkcję.

Opiekunem adaptacji zawodowej powinna być osoba mająca doświadczenie, umiejętności i praktyczną wiedzę zawodową, wykazująca chęci i umiejętności do ich przekazywania i ciesząca się autorytetem w zespole. Wpływ opiekuna na przebieg procesu adaptacji zależy nie tylko od jego wiedzy i umiejętności zawodowych, ale także od jego postawy, zaangażowania i osobowości. Osoba taka powinna charakteryzować się zmysłem obserwacyjnym, umiejętnością wnikliwego słuchania oraz wysoką kulturą osobistą, powinna być pełna zrozumienia, cierpliwa i życzliwa, a także posiadać umiejętność dostosowania się do zmiennych sytuacji [19].

W odniesieniu do pielęgniarek miejsce ich pracy nierozerwalnie jest związane $z$ pacjentem $\mathrm{i}$ jego środowiskiem. Nowo przyjęta pielęgniarka wykonuje czynności zawodowe w obecności pacjenta i jego rodziny, osób oczekujących na pełny profesjonalizm zawodowy, dlatego też relacje między opiekunem a nowo zatrudnioną pielęgniarką powinny być oparte na wzajemnej akceptacji i zaufaniu.

Zwracanie uwagi powinno być dyskretne, pozbawione ironii, nigdy nie powinno następować w obecności pacjentów czy też innych członków zespołu. Opiekun powinien jednocześnie formułować oczekiwania, stawiać zadania zgodnie z zakresem obowiązków, uprawnień i odpowiedzialności oraz przekazywać informacje szczegółowo. Warto zacytować Jona Allana, że ,jednym z ważniejszych czynników motywowania pracowników jest przekazywanie informacji" - dlatego niezbędne wydaje się posiadanie przez opiekuna adaptacji umiejętności słuchania i przekazywania zrozumiałych komunikatów, a zważywszy na pracę zespołową - umiejętności komunikacji interpersonalnej [20].

Poprzez program adaptacji opiekun przygotowuje pracownika do samodzielnej pracy i podejmowania przez niego decyzji. Działania opiekuna ukierunkowane są na praktyczne wdrożenie posiadanych przez pracownika umiejętności zawodowych i udoskonalenie nowych wymaganych na stanowisku pracy. Wykształcenie poczucia odpowiedzialności za wykonane zadania oraz wzmocnienie motywacji i wiary we własne możliwości tworzą poczucie przywiązania pracownika do miejsca pracy.

Opiekun zawodowy, który ma największy kontakt z osobą nowo zatrudnioną, powinien mieć decydujące zdanie w ocenie końcowej odnoszącej się do przydatności pracownika na danym stanowisku. Błędny wybór i niewłaściwe dostosowanie metod wspierania pracownika w okresie adaptacji zawodowej wiążą się niejedno- 
krotnie z brakiem efektów lub efektami przeciwnymi do zamierzonych oraz z generowaniem wysokich kosztów.

Pracownik, któremu nie przydzielono opiekuna, czuje się pozostawiony sam sobie, jest zmuszony samodzielnie rozpoznawać specyfikę zadań na stanowisku pracy oraz analizować uwarunkowania w funkcjonowaniu organizacji. Skutkuje to popełnianiem przez niego błędów oraz zaburza przepływ informacji. Przykre doświadczenia nabyte przez pracownika skutkują jego zniechęceniem do pracy, utratą zaufania do firmy. Mogą być przyczyną odejścia z pracy lub w skrajnych przypadkach - rezygnacji z wykonywania wyuczonego zawodu [2].

\section{Kwalifikacje i kompetencje pracownika}

Kwalifikacje i kompetencje zawodowe to układ tworzony przez: wiedzę, umiejętności i cechy osobowości, pozwalający rozwiązywać zadania na stanowiskach pracy wyszczególnionych w opisie zawodu. Umiejętności zależnie od rodzaju prac są w większym lub mniejszym stopniu uwarunkowane posiadaniem odpowiedniej wiedzy, przy czym nie chodzi tu o wiedzę odpowiadającą jakiemukolwiek przedmiotowi teoretycznej nauki, lecz o interdyscyplinarną wiedzę, dostosowaną do rodzaju zadań zawodowych i do dziedziny działalności pracowniczej [21].

Odpowiednio ukształtowane kompetencje zawodowe umożliwiają pracownikom nabycie uprawnień i pełnomocnictw potrzebnych do podejmowania określonych działań, a ich zakres jest uzależniony od stopnia wykształcenia, odbytych szkoleń oraz umiejętności [22].

Kompetencje można podzielić na:

1) kompetencje osobowościowe - związane $z$ indywidualną realizacją zadań, które mają wpływ na ogólną jakość ich wykonania (szybkość, sumienność, profesjonalizm);

2) kompetencje społeczne - związane z kontaktem z innymi ludźmi, które decydują o skuteczności współpracy, porozumiewania się i wywierania wpływu na innych [23].

W odniesieniu do stanowisk pielęgniarskich SPDSK w Warszawie modele kompetencyjne są ukierunkowane na zadania i uwarunkowania środowiskowe związane z pracą pielęgniarki.

Kompetencje określające zdolność pielęgniarki do pracy w trudnych warunkach pod wpływem stresu to: odpowiedzialność, asertywność, odporność na stres oraz wytrwałość.

Kompetencje określające zaangażowanie w realizowaniu powierzonych zadań to:

1) profesjonalizm i etyka,

2) zaangażowanie, samodzielność,
3) sumienność i dokładność,

4) dążenie do rozwoju.

Kompetencje określające umiejętności organizowania pracy i zarządzania:

1) planowanie i koordynowanie,

2) delegowanie,

3) zarządzanie zespołem,

4) organizacja pracy,

5) kompetencje ukierunkowane na pracę zespołową,

6) praca zespołowa,

7) budowanie relacji,

8) szkolenie i uczenie,

9) orientacja na pacjenta/klienta.

Wypracowane modele kompetencyjne są wykorzystywane w ocenie kompetencji kandydatów do pracy w procesie rekrutacji, określaniu wymagań, planowaniu awansów, motywowaniu, kontrolowaniu i w ocenie okresowej pracownika.

\section{Piśmiennictwo}

1. Słownik wyrazów obcych. Warszawa: PWN; 1991. 19.

2. Grünhol E. Adaptacja zawodowa pielęgniarek, http://www. ptpaii gda.ngo24.pl/default.asp (data dostępu: 6.05.2013).

3. Jasiński Z (red.). Zarządzanie pracą. Organizowanie, planowanie, motywowanie, kontrola. Warszawa: Agencja Wydawnicza Placet; 1999. 133.

4. Ciekanowski Z. Metody wdrażania i proces adaptacyjny pracowników. Płońsk: Powiatowy Urząd Pracy w Płońsku; 2010. 12.

5. Ksykiewicz-Dorota A (red.). Zarządzanie w pielęgniarstwie. Podręcznik dla studentów studiów magisterskich wydziałów pielęgniarstwa oraz wydziałów nauki o zdrowiu. Warszawa: PZWL; 2005. 222.

6. Chudy S. Ekonomia i organizacja firmy handlowej. Poznań: Wyd. eMPi2; 1997.

7. Juchowicz M (red.). Narzędzia i praktyka zarządzania zasobami ludzkimi. Warszawa: Poltex; 2003. 93.

8. Netografia, http://pl.wikipedia.org/wik i/Rekrutacja 2; http://wazniak.mimuw.edu.pl /index.php (data dostępu: 6.05.2013).

9. Sajkiewicz A. Harmonizacja pracy i czynniki społeczne, ekonomiczne i organizacyjne. Warszawa: PWE; 1986. 41.

10. Król A, Ludwiczyński A. Tworzenie kapitału ludzkiego organizacji. Warszawa: PWN; 2006.

11. Rutkowski T. Opisy stanowisk pracy metoda KPRM, www. sgh.waw (data dostępu: 5.05.2013).

12. Tomaszewska R. Opis stanowiska pracy w praktyce. Warszawa: Wyd. Rozwoju Kapitału Ludzkiego GURKL.pl; 2010. 10.

13. Szczygieł M. Opinia prawna w sprawie udzielania przez pielęgniarki/położne świadczeń zdrowotnych nie należących do ich kompetencji. Bielsko-Biała, dnia 6 sierpnia 2012 r., http://www.boipip.org.pl/index.php?option=com_ content\&view=article\&id=127:opinia-prawna-2012-08-01\&catid=19\&ltemid=166 (data dostępu: 5.05.2013).

14. Karkowska D, Włodarczyk W. Prawo medyczne dla pielęgniarek. Warszawa: Wolters Kluwer; 2013.

15. Rogala-Pawelczyk G. Odpowiedzialność pielęgniarki i położnej, http://smp.org.pl (data dostępu: 5.05.2013).

16. Bukowski K. Jak określać zakres obowiązków. Rzeczpospolita z dn. 4.10.1996, dodatek Praca - Specjaliści - Zarządzanie. 
17. Baronowska-Skimina A. Zakres obowiazków pracownika nie tylko na piśmie, eGospodarka.pl (data dostępu: 31.03.2009).

18. Zuzewicz K (red.). Zmęczenie układu mięśniowo-szkieletowego - stary problem cywilizacyjny. Bezpieczeństwo Pracy - Nauka i Praktyka. 2000; 9: 28-29.

19. Mleczewska M. Adaptacja zawodowa, http://www.sensup.pl/artykuy/adaptacja-zawodowa.html (data dostępu: 21.05.2013).

20. Allan J. Motywowanie. Warszawa: Wyd. Samorządowe FRDL; 1999. 78

21. Goźlińska E, Szlosek F. Podręczny słownik nauczyciela kształcenia zawodowego. Radom: Wyd. Instytutu Technologii Eksploatacji; 1997.

22. Ciechaniewicz W, Ślusarska B, Zarzycka D, Zahradniczek K (red.). Dawca i biorca pielęgnowania. Podstawy pielęgniarstwa. Lublin: Wyd. Czelej; 2004. 297.

23. Kubat M. Kompetencje zawodowe, http://www.wup.lodz.pl/ files/ciz/ciz_Kompetencje_zawodowe.pdf. (data dostępu: 20.05.2013).
Artykuł przyjęty do redakcji: 07.05.2016

Artykuł przyjęty do publikacji: 11.07.2016

Źródło finansowania: Praca nie jest finansowana z żadnego źródła. Konflikt interesów: Autorzy deklarują brak konfliktu interesów.

Adres do korespondencji:

Joanna Gotlib

ul. Żwirki i Wigury 61

02-091 Warszawa

tel.: 225720 490, fax: 225720491

e-mail: joanna.gotlib@wum.edu.pl

Zakład Dydaktyki i Efektów Kształcenia

Warszawski Uniwersytet Medyczny 